\title{
National panorama of adolescent pregnancy in Mexico: lessons learned in a six-year period
}

\author{
Pablo Kuri-Morales, ${ }^{1}$ Rosalinda Guevara-Guzmán, ${ }^{2}$ Vivian Phillips-Gutiérrez, ${ }^{2}$ Anayeli Mota-Sánchez² \\ and Claudia Díaz-Olavarrieta ${ }^{*}$

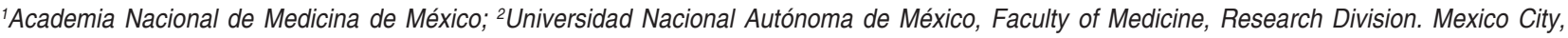 \\ Mexico
}

\begin{abstract}
Globally, adolescent pregnancy constitutes a serious public health problem of a multifactorial nature. Specifically for women, it entails various educational, economic and social implications that affect their life project and widen the social gaps in this age group. Furthermore, adolescent girls are more vulnerable because of the health risk involved with pregnancy at a younger age. According to the World Health Organization, "the probability of maternal death is twice as high in adolescents in comparison with women aged between 20 and 30 years, and for those younger than 15 years, the risks are five times higher". In general, adolescents are in great need for education on sexual and reproductive health issues, which should be aimed at increasing information and knowledge about correct use and access to modern contraceptive methods, as well as at demystifying fears and beliefs around their possible side effects. Ensuring proper counseling with trained personnel is equally vital. Public institutions have a social responsibility to support efforts aimed at preventing adolescent pregnancy, based on relevant lines of action and health policies.
\end{abstract}

KEY WORDS: Adolescent pregnancy. Sexual health. Public health policies. Mexico.

\section{Panorama nacional del embarazo precoz en México: lecciones aprendidas en un sexenio}

\section{Resumen}

En el mundo, el embarazo adolescente constituye un grave problema de salud pública de índole multifactorial. Específicamente para la mujer conlleva diversas implicaciones educativas, económicas y sociales que afectan su proyecto de vida y amplían las brechas sociales en este grupo etario. Asimismo, las adolescentes son más vulnerables por el riesgo en salud que implica un embarazo a corta edad; según la Organización Mundial de la Salud, "la probabilidad de muerte materna es dos veces más en las adolescentes respecto a las mujeres que se encuentran entre los 20 y 30 años de edad, y para las menores de 15 años los riesgos son cinco veces mayores". En general, las y los adolescentes experimentan una gran necesidad de educación en temas sobre salud sexual y reproductiva, la cual debe dirigirse al aumento de información y conocimientos sobre el uso correcto y acceso a métodos anticonceptivos modernos, así como a desmitificar los temores y creencias en torno a sus posibles efectos secundarios. Asegurar una consejería adecuada y con personal capacitado es igualmente vital. Las instituciones públicas tienen la responsabilidad social de respaldar los esfuerzos encaminados a prevenir el embarazo adolescente, con base en las líneas de acción y políticas sanitarias.

PALABRAS CLAVE: Embarazo adolescente. Salud sexual. Políticas de salud pública. México.

Correspondence:

${ }^{*}$ Claudia Díaz-Olavarrieta

E-mail: cdiazolavarrieta@unam.mx
Gac Med Mex. 2020;156:150-155 Contents available at PubMed www.gacetamedicademexico.com 0016-3813/@ 2020 Academia Nacional de Medicina de México, A.C.. Published by Permanyer. This is an open access article under the CC BY-NC-ND license (http://creativecommons.org/licenses/by-nc-nd/4.0/). 


\section{Introduction}

According to figures from the World Health Organization, approximately 16 million adolescents aged 15 to 19 years and one million girls younger than 15 give birth each year, ${ }^{1}$ most of them in countries like Mexico, considered by the World Bank as having a middle-income economy, and in countries with high poverty and marginalization rates. ${ }^{2}$

Globally, complications during pregnancy and delivery are the second cause of death among adolescents. Annually, around three million young females with unwanted pregnancies undergo unsafe abortions, practiced under risky conditions by untrained personnel. ${ }^{3}$ Even when since 1990 there has been a considerable decrease in adolescent fertility rates worldwide, this reduction has been irregular and $11 \%$ of all births are estimated to still occur in girls or female adolescents, out of which $95 \%$ live in countries with middle and low human development rates. In 2014, global average fertility rate among female adolescents aged 15 to 19 years was 49 per 1000 .

According to estimates of the National Population Council (Conapo - Consejo Nacional de Población) for 2015 and 2019, age-specific fertility rate (ASFR, defined as the number of births per thousand women in an age group) in adolescents aged 15 to 19 years corresponded to the international indicator Mexico is committed to in the framework of the Sustainable Development Goals ${ }^{4}$ and at the Montevideo Consensus. ${ }^{5}$ In 2015, the ASFR figure among adolescents aged 15 to 19 years was 74.3 , and it is estimated that in 2019 final count it will be 69.5. The source of this information comes from Conapo preliminary estimates based on the 2016-2050 Population Projections. ${ }^{6}$ Adolescent fertility estimates for girls aged 10 to 14 years constitute a methodological challenge, since the measure used is not a rate, but a ratio. This is because it is assumed that the majority of girls aged 10 and 11 do not yet have their first menstruation (denominator), and therefore they cannot be considered as being exposed to the risk of pregnancy.

The fertility ratio and rate in girls and female adolescents aged 10 to 14 and 12 to 14 years, approved by Inter-Institutional Group for the Prevention of Adolescent Pregnancy ${ }^{7}$ to monitor the magnitude of births in girls younger than 15 years, are not figures that are officially used but as a mechanism for follow-up and evaluation of the National Strategy for Adolescent Pregnancy Prevention. ${ }^{8}$ The prevention and intervention efforts carried out by different government branches are vast and innovative; however, adolescent pregnancy is a phenomenon where complex variables intersect and often do not respond to successful strategies that have been implemented to combat other health problems.

The adolescent pregnancy epidemic has been studied in a fragmented manner as a consequence of the gender inequality that adversely affects girls and female adolescents living in rural communities or metropolitan periurban areas of high marginalization. ${ }^{9}$ The adolescent pregnancy epidemic is the result of various problems, including:

- The quality of the education that is offered to young people, which does not allow them to design an ambitious life plan where reproduction is postponed for later ages; ${ }^{10}$

- A socio-cultural environment where motherhood is seen as a value that exceeds academic, professional or personal achievements; ${ }^{11}$

- Lack of real access to contraceptive methods that young females can use and to evidence-based knowledge, including last-generation reversible methods designed for nulliparous women..$^{12}$

- Intergenerational transmission of poverty, whereby behavioral patterns are especially replicated from mothers to daughters; ${ }^{13}$

- Reproductive coercion, ${ }^{14}$ another manifestation of gender-based violence, and the sexual harassment or violence that young women suffer daily within their homes and in their environment, ${ }^{15}$ which limits their capacity to negotiate safe sex.

- The fact that the lower the reproductive age, the lesser the spacing of children and the larger the number of male partners that support women to provide for their families. ${ }^{16}$

The biological and social consequences of adolescent pregnancy include the following:

- A higher mortality rate during delivery and postpartum,${ }^{17}$ as a result of undernourishment, obesity or overweight before, during and after delivery. ${ }^{18}$

- Children with low birth weight. ${ }^{19}$

- Increase in the number of households headed by women, ${ }^{20}$ which are historically poorer.

- Illiteracy, which is more common in females. ${ }^{21}$

- An explosion in the use of social networks among young females, which presents an aspirational image that hardly finds an objective translation in their daily living. ${ }^{22}$

All this, coupled to a lack of political will of some groups and the conservatism of factual powers, ${ }^{23}$ which 


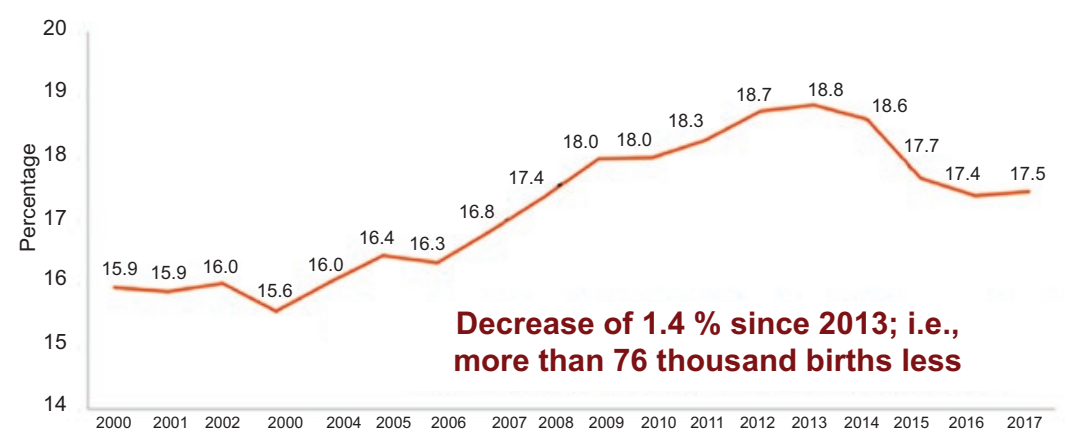

Figure 1. Percentage of births in child and adolescent mothers (younger than 20 years), Mexico, 2000-2017. Source: INEGI. Births per registration year according to maternal age at birth, including mothers with habitual residence abroad, 2019.

prevent young females and women from exercising their constitutional right to a life free of violence, ${ }^{24}$ from having access to a wide range of methods for family planning $^{25}$ offered by duly trained health personnel in youth-friendly services, ${ }^{26}$ including voluntary termination of pregnancy (VTP) within the first 20 weeks of gestation when the pregnancy is the result of rape or sexual violence, or termination of pregnancy within the first 12 weeks for other reasons, which is a procedure that was decriminalized in Mexico City in April 2007 and that can be performed legally, safely and free of charge in Mexico City's Ministry of Health facilities. ${ }^{25,27}$

Since 2003, access to legal and safe abortion has been a priority for the World Health Organization., ${ }^{3,28}$ The Latin American and Caribbean region has the most restrictive abortion legislation, ${ }^{29}$ even when compared to the legislation in force in Sub-Saharan Africa. Adolescent pregnancy is the result of the aforementioned social, cultural, educational and historical determinant factors, and has consequences that have not been systematically explored, such as the risk to the health of the mother-child binomial, at early stages of life, and in the course of adulthood. ${ }^{30}$ Another important association is that which links early pregnancy with maternal metabolic status, since a high incidence of metabolic syndrome has been identified in Mexican women, with reports suggesting that early pregnancy increases this risk. ${ }^{31}$

\section{World situation and the case of Mexico}

Pregnancy in girls and female adolescents, a problem that affects practically the entire world, also causes more than 70,000 deaths due to complications associated with pregnancy and childbirth, with at least 3.2 million unsafe abortions being estimated to occur. ${ }^{32}$
In Mexico alone, more than 2.2 million births were recorded in 2017 , out of which $17.5 \%$ occurred in females aged between 10 and 19 years, i.e. slightly more than 390,000 , out of which 9748 were the result of conception in girls aged between 10 and 14 years. $^{33}$

\section{Institutional response}

In view of this panorama, the World Health Organization has proposed various strategies to address the problem, including the limitation of marriage before 18 years of age, an increase in the offer of family planning methods, a reduction of unsafe abortions and an increase of skilled care before, during and after delivery. ${ }^{34}$

In Mexico, the National Strategy for the Prevention of Pregnancy in Adolescents was launched in January 2015 , whose main objective is to reduce the number of adolescent pregnancies in Mexico with absolute respect for human rights, particularly sexual and reproductive rights, and reach two measurable goals by 2030: to reduce birth rates in girls aged 10 to 14 years to zero, and to reduce age-specific fertility rate in adolescent females aged 15 to 19 years by $50 \%$. Figures 1 to 3 show the trend of births in child and adolescent mothers during the 2000-2017 period.

The National Population Council (Conapo) was entrusted with the task of coordinating the strategy, where different government entities participated: the Ministries of Health, Public Education, Social Development, the National Women's Institute and social security institutions.

Various actions were proposed, including the creation of the Inter-institutional Group for the Prevention 


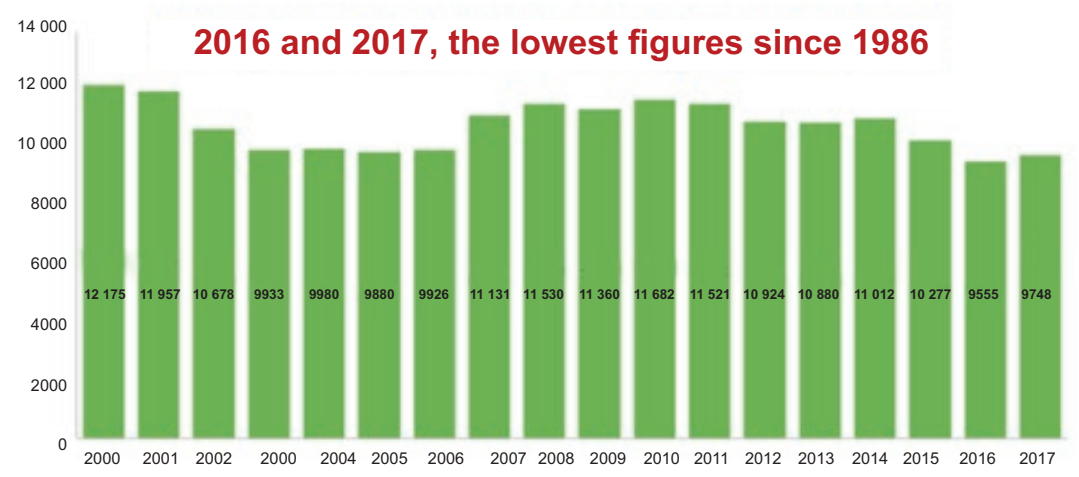

Figure 2. Births in mothers younger than 15 years, Mexico, 2000-2017. Source: INEGI. Births per registration year according to maternal age at birth, including mothers with habitual residence abroad, 2019.

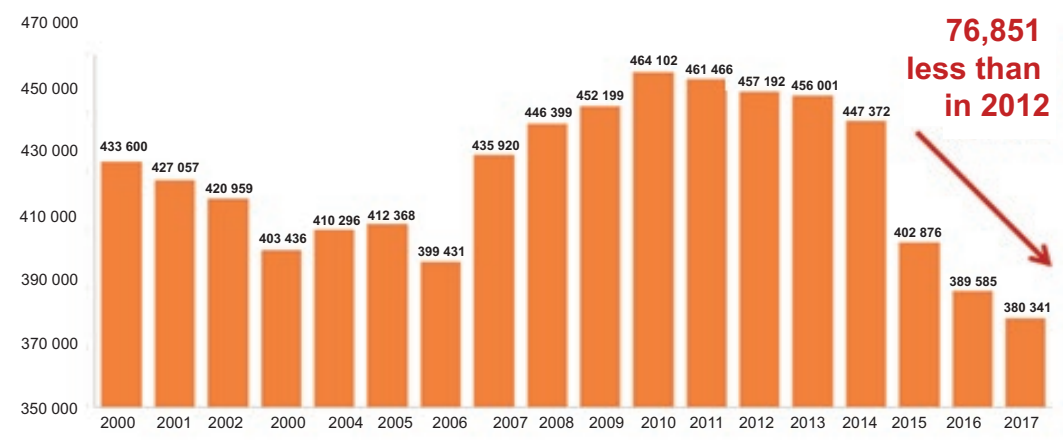

Figure 3. Births in mothers aged 15 to 19 years, Mexico, 2000-2017. Source: INEGI. Births per registration year according to maternal age at birth, including mothers with habitual residence abroad, 2019.

of Pregnancy in Adolescents (as a technical coordination central element), the training of human resources that were responsible for making the operational translation of the strategy, strengthening of Adolescent-Friendly Services, centralized purchase of contraceptives, focalization of actions, and dissemination and evaluation of the strategy. The Model of Comprehensive Care of Sexual and Reproductive Health for Adolescents (MAISSRA - Model de Atención Integral a la Salud Sexual y Reproductiva) was also developed and published. Below, some of the referred actions are described.

\section{Training}

Various face-to-face and distant activities were carried out to train personnel, mainly health personnel, in the application of the MAISSRA and the Official Mexican Standard NOM-047-SSA2-2015, for the health care of the group aged from 10 to 19 years, a complicated task due to the multiplicity of stakeholders and participants.

\section{Adolescent-friendly services}

Over the last six years, these services did increase by $146.9 \%$. By December 2018, there were 2605; $83.6 \%$ of all municipalities in the country have at least one friendly service; in 2017 and 2018, more than 900 thousand adolescents were provided care annually in friendly services, between two and three events of care a year per adolescent.

A significant attendance of children younger than 15 years and adolescent males has been observed; the most demanded services are guidance-counseling, prevention and care of sexually transmitted infections and prescription of contraceptives. ${ }^{35}$

It should be noted that these services are looked after by doctors, nurses or psychologists, but the presence of trained young people who support the operation of friendly services is highly relevant. 


\section{Purchase of contraceptives}

The decision was made to centralize the purchases of family planning supplies, given that some states were not acquiring them. Between 2014 and 2018, more than 4 billion pesos were invested for this purpose, and although not all health units were necessarily reached with all the acquired methods, their supply was increased. Between 12 and 14 item keys (different methods) were made available to state health services, according to a planning exercise where the population to be protected and the health units where they were to be distributed, among other issues, were considered. From condoms to long-acting reversible contraception methods (e.g., implants) were acquired.

\section{Focalization}

All 32 states prioritized pregnancy prevention strategies in girls and female adolescents in 200 municipalities and 135 health jurisdictions, which comprised $56.3 \%$ of females aged 15 to 19 years and covered $54.1 \%$ of total live births in mothers aged 10 to 14 years and $57.9 \%$ of live births in mothers aged 15 to 19 years; $89 \%$ of the 200 priority municipalities had at least one Adolescent-Friendly Service.

\section{Conclusions}

In Mexico, the demographic bonus lost for a country, ${ }^{36}$ as well as the long-term metabolic, neurocognitive and social consequences that are documented, converge in adolescent pregnancy. It is mandatory and urgent to design educational health interventions and cultural norms with an emphasis on adolescent girls life plan. These interventions should be early, evaluated, replicable and sustainable throughout the country. Adolescent pregnancy continues to be one of the main factors that contribute to maternal and child mortality and to perpetuate the circle of disease and poverty. Not addressing this problem is to underpin a form of planned poverty. ${ }^{37}$

There has been an institutional response that has to be evaluated and, if necessary, modified. Some encouraging, although insufficient, achievements have been obtained. It is desirable to continue with that, which after being assessed, shows a positive contribution to address the problem, and to modify or eliminate everything that does not have an impact on the reduction of adolescent pregnancies.

\section{References}

1. Adolescent Pregnancy. Suiza: World Health Organization; 2018.

2. El Banco Mundial [sitio web]. México: Evaluación del programa de país: Evaluación del apoyo del Grupo del Banco Mundial a México (2008-17): Panorama General. Independent Evaluation Group. EE. UU.: World Bank Group; 2018.

3. World Health Organization [sitio web]. Safe abortion: technical \& policy guidance for health systems. Legal and policy considerations: laws and policies on abortion should protect women's health and their human rights. Suiza: World Health Organization; 2015.

4. El cumplimiento de la agenda 2030 y los objetivos de desarrollo sostenible en México. México: Gobierno de la República; 2017.

5. Comisión Económica para América Latina y el Caribe. Consenso de Montevideo sobre población y desarrollo: Cepal; 20138.

6. Consejo Nacional de Población. Proyecciones de la población de México y de las entidades federativas 2016-2050. México: Conapo; 2018.

7. Consejo Nacional de Población. Seguimiento del Grupo Interinstitucional para la Prevención del Embarazo en Adolescentes (GIPEA). México: Conapo; 2018.

8. Grupo Interinstitucional para la Prevención del Embarazo en Adolescentes. Estrategia Nacional para la Prevención del Embarazo en Adolescentes (ENAPEA). Informe 2016. México: 2016.

9. Jiménez GA, Granados CJA, Rosales FRA. Embarazo en adolescentes de una comunidad rural de alta marginalidad. Un estudio mixto de caso. Salud Publica Mex. 2017;59:11.

10. Grupo Interinstitucional para la Prevención del Embarazo en Adolescentes. Estrategia Nacional para la Prevención del Embarazo en Adolescentes (ENAPEA). Informe 2018; México: 2018.

11. Estadísticas a propósito del día de la madre. México: Instituto Nacional de Estadística y Geografía; 2018.

12. Hall AM, Kutler BA. Intrauterine contraception in nulliparous women: a prospective survey. J Fam Plann Reprod Health Care. 2015;42:36-42.

13. González E, Leal I, Molina T, Chacón P. Patrón intergeneracional del embarazo adolescente en las hijas de una cohorte de mujeres que controlaron su primer embarazo en un centro integral para adolescentes embarazadas. Rev Chil Obstet Ginecol. 2013;78:282-289.

14. Gupta J, Falb KL, Ponta O, Xuan Z, Campos PA, Gómez AA, et al. A nurse-delivered, clinic-based intervention to address intimate partner violence among low-income women in Mexico City: findings from a cluster randomized controlled trial. BMC Med. 2017:15:128.

15. Organización Mundial de la Salud. Comprender y abordar la violencia contra las mujeres. Suiza: OMS; 2018.

16. Motherhood in childhood. Facing the challenge of adolescent pregnancy. United Nations Population Fund: EE. UU.: 2013.

17. Instituto Nacional de Estadística y Geografía. Muerte materna y muertes evitables en exceso. México: INEGI; 2014

18. Papathakis PC, Singh LN, Manary MJ. How maternal malnutrition affects linear growth and development in the offspring. Mol Cell Endocrinol. 2016;435:40-47.

19. Karataș।ı V, Kanmaz AG, İnan AH, Budak A, Beyan E. Maternal and neonatal outcomes of adolescent pregnancy. J Gynecol Obstet Hum Reprod. 2019;48:347-350.

20. Zabludovsky G. Las mujeres en los ámbitos de poder económico y político de México. Rev Mex Cienc Polit Soc. 2015;250(223):61-94.

21. Navarro DM, Narro-Robles J, Orozco-Hernández L. La mujer en México: inequidad, pobreza y violencia. Rev Mex Cienc Polit Soc. 2014;59:117147.

22. Spies Shapiro LA, Margolin G. Growing up wired: social networking sites and adolescent psychosocial development. Clin Child Fam Psychol Rev. 2014:17:1-18.

23. Blancarte R. Religión y sociología; cuatro décadas alrededor del concepto de secularización. Estudios Sociológicos. 2012;30:59-81.

24. Norma Oficial Mexicana NOM-046-SSA2-2005, violencia familiar, sexual y contra las mujeres. Criterios para la prevención y atención. México: Diario Oficial de la Federación; 2009 Mar 24.

25. Norma oficial mexicana NOM 005-SSA2-1993, de los servicios de planificación familiar. México: Diario Oficial de la Federación 1994 May 30.

26. Norma oficial mexicana NOM-047-SSA2-2015, para la atención a la salud del grupo etario de 10 a 19 años de edad. México: Diario Oficial de la Federación; 2015 Ago 12.

27. Flores-Pérez E, Amuchástegui-Herrera A. Interrupción legal del embarazo: reescribiendo la experiencia del aborto en los hospitales públicos del Distrito Federal. Género y Salud en Cifras. 2012;10:21-30.

28. World Health Organization Safe abortion: technical and policy guidance for health systems. Suiza: WHO; 2012. 
Kuri-Morales $\mathrm{P}$, et al.: Adolescent pregnancy in Mexico

29. The world's abortion laws 2014. EE. UU.: Center for Reproductive Rights; 2014.

30. Sámano R, Martínez-Rojano H, Robichaux D, Rodríguez-Ventura AL, Sánchez-Jiménez B, Segovia S, et al. Family context and individual situation of teens before, during and after pregnancy in Mexico City. BMC Pregnancy Childbirth. 2017;17:382.

31. Chang T, Choi H, Richardson CR, Davis MM. Implications of teen birth for overweight and obesity in adulthood. Am J Obstet Gynecol. 2013;209:110-117.

32. World Health Organization Preventing early pregnancy and poor reproductive health outcomes among adolescents in developing countries. Suiza: WHO; 2011.
33. Instituto Nacional de Estadística y Geografía. Estadísticas vitales. Natalidad 2017. México: INEGI; 2018.

34. Organización Mundial de la Salud. Salud de la madre, el recién nacido, del niño y del adolescente. Suiza: OMS; 2017.

35. Dirección General de Información en Salud Servicios otorgados SIS. Cubos dinámicos. México: Secretaría de Salud; 2019.

36. Amjad S. MacDonald I, OsornionVargas A. Social determinants of health and adverse maternal and birth outcomes in adolescent pregnancies: a systematic review and meta-analysis. Paediatr Perinat Epidemiol. 2019;33:88-99.

37. Bruce J. The difficulties of 'living while girl'. J Virus Erad. 2016; 2:177-182. 